\title{
Bakara Sûresi 183-185. Âyetler Çerçevesinde Ramazan ve Orucun İ̧̧ârî Yorumu
}

\author{
Adnan Arslan \\ Doç. Dr., Bilecik Şeyh Edebali Üniversitesi (ROR ID: 00dzfx204) \\ İslami İlimler Fakültesi, Arap Dili ve Belâgâti Anabilim Dal,, \\ Associated Professor, Bilecik Şeyh Edebali University, Faculty of Islamic Sciences, Division of Basic Islamic Sciences \\ Departmant of Arabic Langauge and Rhetoric \\ Bilecik/Türkiye \\ adnan.arslan@bilecik.edu.tr \\ ORCID: 0000-0002-3989-6612
}

\section{The Fast and Ramadan in Ishari Commentaries in the Frame of 183-185th Verses of Șūrat al-Baqarah}

\begin{abstract}
Undoubtedly, one of the worships that are the symbols of Islam is the Ramadan fast. Verses 183/184/185 of Șūrat al-Baqara which states the obligatory fasting of Ramadan are interpreted by commentators (mufassir) within the framework of Islamic law discipline and the fiqh (Islamic law) terms of worship in question are determined in the presence of hadiths. The verses of fasting, which are accepted as law verses (aḥkām) have been interpreted in terms of fiqh as well as by tafsir scholars who are members of the school known as Ishari commentary (sufi interpretation) in the tafsir literature. The Ishari commentaries have emerged from the idea that the verses bear signs of hidden meanings other than their literal meanings. In these commentaries, the subjects such as Ramadan, fasting, seeing the crescent, sickness and voyage are grippingly interpreted by Sufi-oriented commentators.

In this study, how prominent commentators of the Ishari tafsīr school interpreted these verses were examined. Due to the fact that similar interpretations are repeated in commentaries, the explanations that we find more original have been chosen. According to these interpretations Ramadan is a sign of the life of the human being, seeing the crescent moon is seeing (ru'ya) of the God, and the state of illness and voyage are signs of the states that happened to Sufi during the course of his life. It is stated that a fast in the sense of staying away from the things determined by the fiqh is "the fast of the common people", and the fasting of the people called havâs (special) is not only eating/drinking but also avoiding all prohibited things. According to these interpretations repeated in many tafsir, the fast of the tongue is to stay away from lies, prostitution and backbiting. The fasting of the eye is not seeing in case of heedlessness and doubt. The fast of the ear is to clog the ear against the things that are abrogated. The fasting of the soul is to restrain hopes, ambition and lust for the future. The heart also has a fast. His fast is to turn away from the adornment and love of the world. The soul's thing is not to seek the flavors and
\end{abstract}

Intihal Taraması/Plagiarism Detection: Bu makale intihal taramasından geçirildi/This paper was checked for plagiarism Geliş/Received: 14 Nisan/April 2020 | Kabul/Accepted: 22 Ağustos/August 2020 | Yayın/Published: 20 Eylül/September 2020 Atıf/Cite as: Adnan Arslan, "Bakara Sûresi 183-185. Âyetler Çerçevesinde Ramazan ve Orucun İşârî Yorumu = The Fast and Ramaḍan in Ishari Commentaries in the Frame of 183-185th Verses of Șūrat al-Baqarah", Eskiyeni 42 (Eylül/September 2020), 1007-1027. https://doi.org/10.37697/eskiyeni.720019

Copyright @ Anadolu Ilahiyat Akademisi/Anatolian Theological Academy, 06050, Ankara, Turkey |www.anilakademi.com CC BY-NC 4.0 | This paper is licensed under a Creative Commons Attribution-NonCommercial License 
bounties of the hereafter. The fasting of the secret (sir) is that refrains from seeing the body of anything except God.

Based on the idea that the verse can have deep meanings beyond its apparent meanings, interpretations corresponding to the terminology of Sufism have been made. In fact, the illness and travel situations that are stated as an excuse for not fasting have found their way into the signs in the ishari tafsir. According to these interpretations a person may be interrupted and disrupted in his spiritual journey from time to time; It may lose enthusiasm and fall into slack humanity. While he is in the pursuit of truth, he may sometimes get tired of the weight of the maqāms (spiritual paths) he follows and show helplessness. In this case, it is his duty to show patience in the face of the futuristic state of affairs until his grace comes to the rescue and rest for a while on his journey. When his heart is salvaged and the morbid states he was exposed to collapse, he can continue his journey, which he could not perform in the past or lagged behind; can make up for the past. It can be said that this interpretation made by the commentator is actually a guide not only for Sufism and sufis but also for all believers. Because the journey to become a perfect Muslim is a bumpy campaign that will continue until the last breath. Surrounded by ascension and descent, spiritual illness and helplessness, the journey of truth is of course not monotonous. In that case, as indicated above, when a believer is at ease for pleasure and pleasure, he should engage in futility, seize the opportunity, and hang with all his might on the oars in the sea of truth. However, on the contrary, when he is exposed to forbidden and spiritual illnesses, he should not be redhanded eating, and he should be satisfied with the fards until he reaches the help of grace and heals.

As far as we can see, these comments will contribute to the more conscious fulfillment of fasting, which is an important principle of the religion of Islam. The interpretations that confirm the prophetic warning in the hadiths are stating that fasting does not consist of being hungry and thirsty adds different dimensions to it. On the other hand, today it is highly probable that the source of some of the quotations and exemplary narratives among Muslims about Ramadan and fasting today is the comments in these ishari commentaries. Therefore, with these interpretations that add depth and influence to the understanding, we believe that the fact that Ramadan and fasting have deep meanings beyond starvation is reinforced. As a result, the study makes a recommendation for other field researchers. That is the issue of making separate studies with the commentaries to be brought together in the context of a certain subject in the ishari commentaries. This is because many impressive interpretations -fiqh-1 bâtın- are scattered in these commentaries on the point of interest of the general reader. We are of the opinion that compiling and explaining them under a specific topic will be beneficial especially against the moral degeneration we have been suffering recently.

\section{Keywords}

Tafsīr, Bursawī, Baklī, al-Qushayrī, Ramaḍan, Fast

\section{Bakara Sûresi 183-185. Âyetler Çerçevesinde Ramazan ve Orucun İşârîY Yorumu Öz}

İslam'ın şiârı/sembolü olan ibadetlerden birisi de kuşkusuz Ramazan orucudur. Ramazan orucunun farziyetini bildiren Bakara sûresi 183/184/185. âyetleri, müfessirler tarafından genel olarak İslam hukuku disiplini çerçevesinde tefsir edilmiş, söz konusu ibadetin fikhîşartları hadisler eşliğinde belirlenmeye çalışılmıştır. Ahkâm âyeti olarak kabul edilen oruç âyetleri, lügavi/fikhî 
açıdan tefsir edildiği gibi tefsir literatüründe işârî tefsir olarak bilinen ekol mensubu müfessirler tarafından da batınî yorumlara tabi tutulmuştur. İşârî tefsirler, âyetlerin lafzî/literal anlamlarından başka hafî/gizli manalara da işaretler taşıdığı düşüncesinden hareketle ortaya çıkmıştır. Bu tefsirlerde Ramazan, oruç, hilalin görülmesi, hastalık ve sefer gibi oruç âyetlerinin ele aldığı konular sûfî eğilimli müfessirler tarafindan ilgi çekici bir şekilde tefsir edilmiştir.

Bu çalışmada işârîtefsir ekolünün öne çıkan müfessirlerinin söz konusu âyetleri nasıl yorumladıkları incelenmiştir. Benzer yorumlar tefsirlerde tekerrür ettiğinden dolayı daha ziyade özgün bulduğumuz izahlar seçilmiştir. Bu yorumlara göre Ramazan insanın ömrüne, hilalin görülmesi Zât-1 ilâhî̀nin rü’yetine, hastalık ve sefer hali ise sûfînin seyr-ü sülûku boyunca başına gelen hallere birer işarettir. Fıkıh ilmince belirlenen şeylerden uzak durma anlamındaki bir orucun "avamın orucu" olduğunu ifade edilmiş, havâs denilen kimselerin orucu ise sadece yeme/içme değil tüm yasaklanan şeylerden uzak durmak olduğu üzerinde durulmuştur. Birçok işârî tefsirde tekrarlanan bu yorumlara göre dilin orucu; yalan, fuhşiyat ve gıybetten uzak durmaktır. Gözün orucu ise gaflet ve şüphe halinde görmemektir. Kulağın orucu ise nehyedilen şeylere karşı kulağı tıkamaktır. Nefsin orucu geleceğe dair ümitleri, hırs ve şehveti dizginlemektir. Kalbin de orucu vardır. Onun orucu dünyanın ziynet ve sevgisine karşı yüz çevirmektir. Ruhunki ise ahiretin lezzet ve nimetlerine talip olmamaktır. Sırrın orucu Allah’ın gayrısının vücudunu görmek ve onlara bir vücut vermekten imtina etmesidir.

Âyetin zahir manalarının ötesinde derûnî anlamlar taşıyabileceği düşüncesinden hareketle tasavvuf terminolojisine tekabül edecek yorumlamalar yapılmıştır. Hatta oruç tutmamaya bir mazeret olarak belirtilen hastalık ve sefer durumları işârî tefsirlerde kendilerine karşıllk bulmuştur. Bu yorumlara göre kişi, manevi yolculuğunda zaman zaman sekteye ve fütura kapılabilir; şevkini kaybedip beşeriyet muktezası gevşekliklere düşebilir. Hakikat peşinde taharride bulunurken kimi zaman uğradığı makamların ağırlığından yorulup acizlik gösterebilir. Bu takdirde ona düşen, inayet imdadına yetişinceye kadar duçar olduğu fütur haleti karşısında sabır göstermesi ve yolculuğunda bir müddet istirahate çekilmesidir. Kalbi selamete erdiği ve maruz kaldığı marazi haller zeval bulduğunda geçmişte eda edemediği yahut geri kaldığı yolculuğuna sâlik devam edebilir; geçmişin telafisini yapabilir. Müfessirin yapmış olduğu bu yorum aslında sadece tasavvuf erbabı için değil tüm mü'minler açısından da istikamet vericidir denilebilir. Zira kâmil bir Müslüman olma yolculuğu son nefese kadar devam edecek engebeli bir seferdir. Yükseliş ve alçalışlarla, manevi hastalık ve acizliklerle çevrili hakikat yolculuğu elbette tekdüze değildir. O halde yukarıda işaret edildiği gibi mü’min şevk ve zevk üzere ferahlı olduğu vakitlerde nafilelerle meşgul olup firsatı değerlendirmeli, hakikat denizinde küreklere var gücüyle asılmalıdır. Lakin tam aksine, fütur ve manevi hastalıklara maruz kaldığında da yese kapılmamalı, inayet yardımına yetişip şifa buluncaya kadar farzlara kanaat etmelidir.

Gördüğümüz kadarıyla bu yorumlar, İslam dininin önemli bir şiarı olan oruç ibadetinin daha bilinçli yerine getirilmesine katkısı sağlayacak niteliktedir. Orucun aç ve susuz kalmaktan ibaret olmadığını bildiren hadislerdeki nebevi uyarıyı teyit edecek mahiyetteki yorumlar oruca farklı boyutlar kazandırmaktadır. Diğer taraftan bugün Müslümanlar arasında Ramazan ve oruç hakkında söylenen özlü sözler ve ibret dolu anlatıların bir kısmının kaynağının bu işâ̂î tefsirlerde geçen yorumlar olması büyük olasılıktır. Dolayısıla anlama derinlik ve etki gücü katan bu yorumlarla Ramazan ve oruç ibadetinin aç kalmanın ötesinde derûnî manaları ihtiva ettiği gerçeğinin pekiştirilmiş olduğu kanaatimizdir. Sonuç olarak çalışma diğer alan araştırmacllarına bir tavsiyede bulunmaktadır. $O$ da işârî tefsirlerdeki belirli bir konu bağlamında bir araya getirilecek yorumlarla müstakil çalışmalar yapılması hususudur. Zira özellikle genel oku- 
yucunun ilgisini çekecek -fikh-1 bâtın- sadedinde nice etkileyici yorumlar bu tefsirlerde serpiştirilmiş bir haldedir. Bunların belirli bir konu başlı̆̆ı altında derlenip izahlarının yapılmasının, hassaten son zamanlarda muzdarip olduğumuz ahlaki yozlaşma karşısında faydalı olacağı kanaatindeyiz.

\section{Anahtar Kelimeler}

Tefsir, Bursevî, Baklî, Kuşeyri, Ramazan, Oruç

\section{Giriş}

خُخْن من القرآن ما شئت لما شئت "Kur’ân'dan dilediğin şey için dilediğini al.”" Harfî olarak çevirdiğimiz bu ibare, eskilerden beri Kur'ân'ın her bir âyetinin sayısız manaları ihtiva ediyor oluşunu veciz bir şekilde ifade etmek üzere dilden dile aktarılagelmiştir. İslam dininin en temel kaynağı olarak Kur'ân'a atfedilen bu değer aslında sadece Kur'ân'a değil, sonsuz manalar içerdiği ve sırlı, gizemli anlamlarla dolu olduğu inancıyla pek çok kutsal metne de isnat edilmiştir. ${ }^{2}$ Kur'ân açısından anlamca bu câmiiyyet/şümul meselesine baktığımızda âyetlerin sınırsız anlamlar ifade ettiğine olan inancımız aslında ilim, irade ve hikmet gibi sıfatlarında mutlak, kayıtsız olan Allah'a

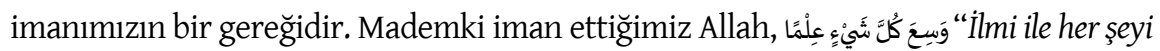
ihata etmiştir" ", tüm varlıkta olmuş/olan/olacak her şey, zaman kaydından münezzeh bir şekilde onun ilminde mevcuttur; o halde ezelî ilminden gelen kelamı da ezelîdir. ${ }^{4}$ Ezeliyete olan bu iman ${ }^{5}$, sahabe döneminden bugünlere kadar Kur'ân'ın sınırlı lafızlarında sınırsız manalar arayışının en temel sâikidir denilebilir. ${ }^{6}$

Yukarıda değindiğimiz bilgiler genel olarak hiçbir Müslüman'ın inkâr etmeyeceği bedihi meselelerdir. Konuyu biraz daha daraltarak tefsire getirdiğimizde Kur'ân'ın mana bakımından sınırsız olduğuna imanın bir yansıması, tefsir edebiyatında hesabını yapamayacağımız kemmiyette tefsirin kaleme alınmış olmasıdır. Telif edilen bu tefsirler birbirinden tamamen ayrı olmadığı gibi birbirinin tekrarı metinler de değildir. Telâhuk-1 efkâr denilen, çı̆̆ın hareketine benzer bir şekilde nesilden nesle yeni yorumlar, yeni izahlar tefsirlerde kendine yer bulmuştur. Bu tefsirlerin bir kısmı belki de çoğu yağmalar, savaşlar, sellerden dolayı yahut kayda değer okuyucu kitlesi

1 Muhammed Hasen b. Alevî b. Abbâs b. Abdilazîz el-Hasenî el-Mâlikî el-Mekkî, Ebvâbu'l-ferac (Beyrut: Dâru'l-Kutubi'l-ïlmiyye, ts.), 74.

2 Nihat Uzun, Kurânn'in Batınî ve İsârî Yorumu Tefsir İlmi Açısından Bâtınî ve İsârî Yorumun ilmî Değeri (İstanbul: Kuramer Yayınları, 2018), 181.

3 Tâhâ 20/98.

4 Ebû Hafs Necmüddîn Ömer en-Nesefî, el-Akâidu'n-Nesefiyye (Suudi Arabistan: Melik Suûd Üniversitesi Kütüphanesi, 213), 16 .

5 Ezel zamandan ve mekândan münezzeh olan, başı ve sonu bulunmayan, hiçbir kayda bağh olmayan Allah'in sifattdır. Zaman içindeki kayıtlar burada geçerli değildir. Yani Allah ezelî ilmiyle her şeyi kuşattı̆ı̆ndan O’nun ilminde geçmiş zaman, şimdiki zaman ve gelecek kavramları yoktur. İlyas Çelebi, "Ezeliyet", Türkiye Diyanet Vakfi İslam Ansiklopedisi (Istanbul: TDV Yayınları, 2016), EK-1/431-432.

6 Kur'ân'ın anlam bakımından zenginliğinin hangi hususlardan kaynaklandığına dair kapsamlı bir çalışma için bk. M. Halil Çiçek, "Kurân'da Anlam Zenginliği", Kur'an Araştırmaları Sempozyumu (İstanbul: y.y.; 2008), 21-46. 
ve siyasi destek vb. bulamadığından kaybolup gitmiştir.7 Ancak önemli sayıda tefsir bugünlere ulaşmış, defalarca basılmıştır. Bu tefsirlerin her birinin alamet-i farika bir hususiyeti vardır. Keşşâfta dil, Mefâtihu'l-Gayb'da kelâm, Câmiu'l-Ahkâm'da fikıh, Nazmu'dDürer'de münasebet, Taberî Tefsiri'nde rivayet vb. özellikler tefsirlerin imtiyazına vesile olmuştur. Müfessirin ilgi ve uzmanlık alanına veyahut yazıldığı dönemin entelektüel ihtiyacına göre farklı tefsir ekolleri ortaya çıkmıştır. Bu ekollerden birisi de işâ̂î tefsir olarak bilinen tasavvuf erbabının kaleme aldığı tefsirlerdir. ${ }^{8}$

Işârî tefsirler, âyetlerin lafzî/literal anlamlarından başka hafî/gizli manalara da işaretler taşıdığı düşüncesinden hareketle ortaya çıkmıştır. 'ं Işârî manalar takdim eden tefsirler, Allah'in vehbi olarak verdiği ilimle veya kalbe ilham ettiği işaret ve bilgilerle yaplabilir. ${ }^{10} \mathrm{Bu}$ itibarla âyetin zahiri manalarını keşfetmek için nahiv, belâgat, delalet ilmi vb. ilimler gerekli olduğu gibi işârî manalarına ulaşmak için de yukarıda değindiğimiz gibi vehbî ilim/ilhama mazhar olmak lüzumu vardır. Söylenen işârî manalar Arap dilinin zâhirine muvafik güzel bir istinbat ise ve bu manaların sıhhatine delalet eden bir delil de varsa, bu tür işârî manalar makbul addedilmiştir. ${ }^{11}$ Işsârî tefsirlerin tarihi, yöntemleri, özellikleri, müfessirleri vb. hakkında akademik çevrelerce o kadar çok şey söylenmiştir ki burada bu bilgileri tekrar etmenin gerekli olmadığını düşünüyoruz. ${ }^{12}$ Dolayısıyla söz konusu literatür için ilgili çalışmalara atıfta bulunmakla yetinerek ${ }^{13}$

7 Örneğin ünlü bir hadis hafızı olan Abd b. Humeyd'e nispet bir edilen bir rivayet tefsiri kayıptır. Muhammed b. Abdullah b. Alî el-Hudayrî, Tefsîru't-tâbiîn (b.y.: Dâru'l-Vatan li'n-Neşr, ts.) 2/984. Eş'arî Mezhebi kelamcılarından İbn Fûrek'in üç ciltlik tefsirinin ilk iki cildi henüz bulunamamıştır. Ebû Bekr Muhammed b. el-Hasen b. Fûrek el-İsfahânî en-Nîsâbûrî ỉbn Fûrek, Tefsiru'l-Kur'ân (ìstanbul: Millet Kütüphanesi, Feyzullah Efendi Bölümü, 50). Yine Rummâni'ye nispet edilen bir tefsirin bir kısmı günümüze ulaşmamıştır. Ebü'l-Hasen Alî b. Îsâ Rummânî, Tefsîru Ebi'l-Hasen erRummânî, thk. Hıdr Muhammed Nebhâ (Beyrut: Dâru'l-Kutubi'l-ilmiyye, ts.), 12. Süyûtînnin kısaca el-i̇tkân adlı eserinde günümüze ulaşmamış Süneyd, İbnü'l-Munzir ve İbn Merdûye/Mürdeveyh gibi ünlü pek çok isimden yapmış olduğu -tefsir alıntıları- kayıp tefsirlerin sayısı hakkında fikir vermektedir. Hâzim Saîd Haydar, Ulûmu'l-Kur'ân beyne'l-burhân ve'l-itkân dirâsetun mukârane (Medîne: Dâru'z-Zamân, 1420), 614. Tefsir, tabakat ve teracim kaynaklarında ismi belirtilen ancak günümüze ulaşmamış tefsirlerin listesi hakkında bir çalışmanın alan araştırmacılarına hedef göstermesi açısından faydalı olacağı kanaatindeyiz.

8 Muhammed Huseyn ez-Zehebî, et-Tefsîr ve'l-mufessirûn (Kâhire: Mektebetu Vehbe, 2000), 2/250306.

9 Nûreddîn Itr, Ulûmu'l-Kur'âni'l-Kerîm (Şam: Matbaatu's-Sabâh, 1993), 97.

10 Yunus Emre Gördük, Tarihsel ve Metodolojik Açıdan İşari Tefsir (İstanbul: İnsan Yayınları, 2012), 39.

11 Mennâ' el-Kattân, Mebâhisun fi ulûmi'l-Kur'ân (Kahire: Mektebetu Vehbe, ts.), 347.

12 Işââ̂ tefsir hakkında Arap dünyasında yapılmış kapsamlı bir çağdaş çalışma için bk. Meşân Suûd Abduluyâsevî, et-Tefsîru'l-işârî mâhiyyetuhû ve davâbiduhû (Beyrut: Dâru'l-Kutubî'l-İlmiyye, 2013).

13 İlgili çalışmalardan birkaçı için bk. Yunus Emre Gördük, Tarihsel ve Metodolojik Açıdan İşari Tefsir (İstanbul: İnsan Yayınları, 2012); Süleyman Ateş, İşârî Tefsir Okulu (Ankara: Ankara Üniversitesi İlahiyat Fakültesi Yayınları, 1974); Şaban Karasakal, Kur'ân'ın İşârî Yorumu (ìstanbul: Rağbet Yayınları, 2016). Süleyman Uludağ, "Işsari Tefsir”, Türkiye Diyanet Vakfi İslam Ansiklopedisi (İstanbul: TDV Yayınları, 2001), 23/424-428; Yunus Emre Gördük, “Tefsir-Te'vîl” Ayrımı ve İşârî Tefsirin Öznel Mahiyeti Bağlamında "Yorum-Algı" Sorunu", Pamukkale Üniversitesi İlahiyat Fakültesi Dergisi 4/7 (Mart 2017), 1-27. 
araştırma konumuz olan işârî tefsirlerde, Ramazan ayı ve oruç ibadetinin nasıl yorumlandığına bakacağız. İşârî tefsir denildiğinde daha ziyade ilk akla gelen isimler ve tefsirleri üzerinden bir tarama yapılacaktır.

\section{Orucun Fazileti Hakkında Hadislerden Genel Bir bilgi}

Kökleri insanlık tarihi kadar eskilere giden oruç, ${ }^{14}$ hadislerde insanı muhafaza eden bir kalkan/zırh şeklinde tarif edilmiş, ${ }^{15}$ misilsiz bir ibadet olarak tavsiye edilmiştir. ${ }^{16} \mathrm{O}$, âhirette cehennem ateşi ile mü’minin arasını sema ve arz kadar uzaklaştıracak bir şefaatçi, ${ }^{17}$ işlenilen günahlara karşı keffâretu'z-zünûb, ${ }^{18}$ Reyyân denilen mahsus kapıdan cennete girmeye vesile, ${ }^{19}$ Allah'ın cemâli ile müşerref olmanın bir yolu ${ }^{20}$ ve ağız kokusunu Allah nezdinde misklerden de güzel hale getiren bir iksirdir. ${ }^{21}$ Oruç, duaların kabul olmasına vesile, ${ }^{22}$ kalbi rahatsız eden öfkelerden kurtaran bir ilaç, ${ }^{23}$ ebedi helâketlere sürükleyen gayr-i meşru şehvetlere karşı bir gem, bir dizgin ${ }^{24}$ büyük bir ihsan olarak bahşedilen bedenimizin zekâtıdır ${ }^{25}$ ve sahuruyla bereket vesilesidir, ${ }^{26}$ sıhhat kaynağıdır. ${ }^{27}$ Bu ibadetin Allah nezdinde ne kadar sevimli olduğu şununla anlaşılır ki oruçlu, unutup yese içse de ona oruçlu olduğu hatırlatılmaz; zira Allah bizzat unutturup yediriyor, hatırlatmayıp içiriyordur. ${ }^{28}$ Oruçlunun iftarı yine Allah nezdinde öyle mübarek bir yemektir ki sair vakitlerde namazın hemen kılınması tavsiye edilirken oruçta bilakis, iftarın acele ile hemen namazdan önce yapılması güzeldir. ${ }^{29}$ Zira hadisin ifade ettiği gibi oruçlunun iki sevinci

14 Recep Demir, “Diğer İnanç Sistemlerinde ve İslâmda Oruç (Karşılaştırmalı Bir Analiz)”, Uluslararası Sosyal Araştırmalar Dergisi 9/42 (Şubat 2016), 1784.

15 Ebû Abdillah Ahmed b. Muhammed Ahmed b. Hanbel, Müsnedu Ahmed b. Hanbel, thk. Şuayb el-Arnavûd (Beyrut: Muessesetu'r-Risâle, 2001), 446/15.

16 Ahmed b. Hanbel, Müsnedu Ahmed b. Hanbel, 36/465. (No. 22149).

17 Ebû Bekr b. Ebî Şeybe, Musannef İbn Ebî Şeybe, thk. Kemâl Yûsuf el-Hût (Riyâd: Mektebetu'r-Ruşd, 1409), 4/214 (No. 19418).

18 İbn Ebî Şeybe, Musannefíbn Ebî Şeybe, 7/449 (No. 37129).

19 Ebû Hâtim Muhammed b. Hibbân b. Ahmed el-Büstî, Sahîh İbn Hibbân, thk. Şuayb el-Arnavûd (Beyrut: Muesesetu'r-Risâle, 1988), 8/206 (No. 3418).

20 Ebû Abdillâh Muhammed b. İsmail el-Buhârî, el-Câmi'u’ṣ-ṣaḥ̂h, nşr. Muhammed Züheyr b. Nasr (b.y.: Dâru Tavki'n-Necât, 1422/2001), “Savm”, 30 (No. 1904).

21 Buhârî, el-Câmi'u'ṣ-ṣahîh, "Savm”, 30 (No. 1904).

22 Ebû Bekr el-Beyhâkî, Şuabu'l-îmân, thk. Abdulalî Abdulhamîd (Bombai: Mektebetu'r-Ruşd, 2003), 9/553 (No. 7060).

23 Ahmed b. Hanbel, Müsnedu Ahmed b. Hanbel, 34/342 (No. 20738).

24 Ahmed b. Hanbel, Müsnedu Ahmed b. Hanbel, 7/184 (No. 4112).

25 Ebû Abdillâh Muhammed b. Yezîd Mâce el-Kazvînî, Sunenu İbn Mâce, thk. Muhammed Fuâd Abdülbâkî (Kâhire: Dâru İhyâi'l-Kutubi'l-Arabiyye, ts.) “Siyâm”, 44 (No. 1745).

26 Ahmed b. Hanbel, Müsnedu Ahmed b. Hanbel, 14/476 (No. 8898).

27 Ebü'l-Kāsım Müsnidü'd-dünyâ Süleymân b. Ahmed b. Eyyûb et-Taberânî, el-Mu'cemu'l-evsat, thk. Tarık b. ivadullah b. Muhammed (Kahire: Dâru'l-Harameyn, ts.), 8/174 (No: 8312).

28 Buhârî, el-Câmi u'ș-șahîh, "Savm”, 30 (No. 1933).

29 Ebü'l-Hasen Alî b. Ömer b. Ahmed ed-Dârekutnî, Sunenu Dârekutnî, thk. Şuayb Arnavûd (Beyrut: muesesetu'r-Risâle, 2004) 2/30 (No. 1095). 
vardır: Biri iftar vaktinde diğeri de Allah'a kavuştuğu günde. ${ }^{30}$ Dolayısıyla Allah, Müslüman'ın iftar vaktindeki o sevinci hemen yaşamasını dilemektedir denilebilir. Tüm bu rivayetler Müslüman'ın sadece ve sadece Allah için “aç ve susuz kalma” külfetini seve seve kabul etmesinin faziletini anlatmaktadır. Her ibadette az çok riyâ tehlikesi varken Allah Resûlü "Oruçta riyâ yoktur." ${ }^{31}$ buyurmuştur. Zira diğer ibadetler bir fiille tezahür ediyorken oruç, tamamen kalbin tertemiz niyetine matuftur; ${ }^{32}$ gösteriş gibi çirkin davranışlara müsait değildir.

\section{Orucun Farziyeti ve Uygulaması Hakkında Âyetler}

Orucun fazileti hakkında sadece bir kısmına yüzeysel olarak değindiğimiz bu hadislerden sonra oruç ibadetinin farziyetini bildiren âyetlere yer vermemiz gerekecektir.

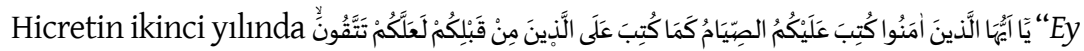
iman edenler! Allah'a karşı gelmekten sakınmanız için oruç, sizden öncekilere farz kılındığı gibi, size de farz kılındı." ${ }^{33}$ âyeti ile farz kılınmıştır. ${ }^{34}$ Bundan doğrudan oruçla ilgili olan iki âyet, oruç ibadetinin icrasında fikhî çerçeveyi çizmekte ve muhtemel istisnai durumlara ait düzenlemeleri ifade etmektedir.

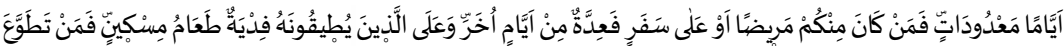

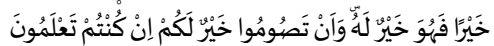

“Ey İnananlar! Oruç, sizden öncekilere farz kılındığı gibi, Allah'a karşı gelmekten sakınasinız diye, size sayıl günlerde farz kılındı. İçinizden hasta olan veya yolculukta bulunan, tutamadığı günlerin sayısınca diğer günlerde tutar. Oruca dayanamayanlar, bir düşkünü doyuracak kadar fidye verir. Kim gönülden iyilik yaparsa o iyilik kendisinedir. Oruç tutmanız eğer bilirseniz sizin için hayırlıdır."35

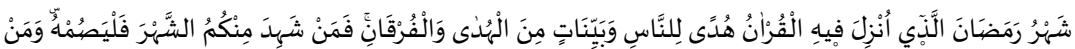

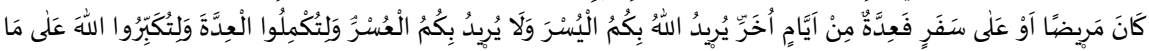

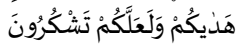

"(O sayılı günler), insanlar için bir hidayet rehberi, doğru yolun ve hak ile batılı birbirinden ayırmanın apaçık delilleri olarak Kur'an'in kendisinde indirildiği Ramazan ayıdır. Öyle ise içinizden kim bu aya ulaşırsa, onu oruçla geçirsin. Kim de hasta veya yolcu olursa, tutamadığı günler sayısınca başka günlerde tutsun. Allah, size kolaylık diler, zorluk dilemez. Bu da sayıyı tamamlamanız ve hidayete ulaştırmasına karşılı Allah'ı yüceltmeniz ve şükretmeniz içindir."36

\footnotetext{
30 Ahmed b. Hanbel, Müsnedu Ahmed b. Hanbel, 15/445 (No. 9714).

31 Beyhâkî, Şuabu'l-îmân, 5/214 (No. 3321).

32 Ebü'l-Fazl Şihâbüddîn Ahmed b. Alî b. Muhammed el-Askalânî, Fethu'l-Bârî, thk. Abdülkâdir Şeybe el-Hamed (Riyâd: Mektebetu'l-Melik Fahd, 1421), 4/129.

33 el-Bakara 2/183.

34 İbrahim Kafi Dönmez, “Oruç”, Türkiye Diyanet Vakfi İslam Ansiklopedisi (İstanbul: TDV Yayınları, 2007), $33 / 417$.

35 el-Bakara 2/184.

36 el-Bakara 2/185.
} 


\section{Oruç Âyetlerinin İşârî Yorumları Hakkında Ön Değerlendirme}

Bu üç âyette görüldügü gibi sırayla; orucun farziyetini ihbâr, yolculuk ve hastalık halinde istisnai durum ve ruhsatlar, oruca zorlanacaklar için belirlenen telâfi bedeli, orucun başlama zamanı gibi noktalarla fikhi çerçeve çizilmektedir. Oruç ibadetinin Müslüman hakkında maddi ve manevi, dünyevi uhrevi pek çok fazilet ve meziyetlerinin anlatıldığı hadisler, bu âyetlerdeki icmali tafsil etmektedir. Ancak bu üç âyetin kelime ve terkipleri, oruç ibadetinin sadece uygulanış biçimini şeklen belirlemek için mi nâzil olmuştur? Hadislerde birçok yönüyle fazileti vurgulanan bir ibadetin Kur'ân lafızlarıyla daha ziyade şekil/biçim/tatbik açıları tespit edilmiş gibi görünmektedir. Iş̧te burada tasavvuf erbabı müfessirlerin bu sözlerimize itirazını duyar gibi oluyoruz. Zira onlar gözle görünen bu şehadet âleminin "zahir"den ibaret olup geriye yahut öteye doğru (mâverâ) diğer âlemlerin ağaç gibi bir tecelli halinde yayılmış ve serpilmiş olduğunu düşünmektedirler. Bu tecelli mertebeleri, zahir-batın ilişkisi içinde birbiriyle bağintil olup, "zat" mertebesinden itibaren batından zahire doğru bir geçiş söz konusudur. Buna göre her bir mertebe bir sonrakinin bâttın ve hakikati; bir öncekinin de zâhiri ve tecellisi durumundadır. ${ }^{37} \mathrm{Bu}$ takdirde emredilen ibadetlerin şekillerinin de pek çok bâtınîi ${ }^{\hat{8}}$ anlamı bulunan bir zâhir olduğu sonucu ortaya çıkmaktadır. ${ }^{39}$ Hatta ibadetlerin özünü teşkil eden manaların önemine yapılan vurgu fikh-ı bâtın kavramını ortaya çıkmıştır. ${ }^{40}$ Öyle ise oruç ibadetini ele alan üç âyette sadece zahiri şartların belirlenmesi vardır denilemez. Hadislerde dediğimiz gibi yüksek bir hasiyete sahip oruç, âyetlerin sadece zahiri manalarına hamledilecek bir ibadet olmamalıdır. ${ }^{41}$ Nitekim orucun aç kalmaktan ibaret olmadığı kişinin oruç ibadetinin özüne uygun olmayan davranış ve ahlak sergilediğinde Allah'ın bu kişinin aç kalmasına ihtiyacı olmadığını belirten hadis, ${ }^{42}$ orucun fikh-1 bâtın yönünü teyit etmektedir. Dolayısıyla âyetlerde geçen zahiri anlamların ötesinde orucun yüksek ve geniş faziletlerine işaret eden mana tabakaları bulunmalıdır. Örneğin; "Eğer hasta iseniz..." âyeti ile kastedilen sadece bedeni hastalıklar olmamalıdır. Zira Kur'ân'ın başka âyetlerinde "hastalık" ile manevi ve

37 Osman Türer, “Tasavvufi Düşüncede İnsan”, Tasavvuf ilmi ve Akademik Araştırma Dergisi (2001), 10. (9-15).

38 Mutasavvıflar dinî ilimleri biri zâhir, diğeri bâtın olmak üzere ikiye ayırrr; hadis, fikıh ve kelâm gibi ilimlere zâhir ilimleri, tasavvufa da bâtın ilmi adını verirler. Zâhirî ilimlerle meşgul olanlara zâhir ulemâsı, rüsûm ulemâsı ve ehlizâhir, kendilerine de bâtın ulemâst ve ehl-i bâtın derler. Süleyman Uludağ, "Bâtın İlmi", Türkiye Diyanet Vakfi İslam Ansiklopedisi (istanbul: TDV Yayınları, 1992), 5/188.

39 İbadetlerin kuru bir kışırdan ibaret kalmaması ve şeklin ötesindeki manaların ihmal edilmemesi hususunda Gazzâlînnin çabaları buna en belirgin örnek olarak sunulabilir. Buna dair bir çalışma için bk. Tuncer Namlı, "Fikıhçıların Allah Algısı -Namaz Örneği-“, Eskiyeni 32 (Bahar 2016), 55-72.

40 Kavramın ayrıntıları hakkında bk. Mustafa Sarıcaoğlu, "ibadetler Bağlamında Zâhirî ve Bâtınî Fıkıh: Gazzâlî Örneği”, İslam Bilimleri Araştırmaları Dergisi 5 (2018), 6-32.

${ }^{41}$ Tasavvufta klasik dönemde adından sıklıkla bahsedilen Ebu Bekir Muhammed Kelâbâzî (öl. 380/990), oruçla ilgili hadisleri bâtınî bir şekilde yorumlamıştır. Bu konuda kaleme alınmış bir çalışma, makalemizde işlediğimiz konuyu daha iyi kavramaya vesile olacaktır. İlgili çalışma için bk. Vahit Göktaş, Illk Dönem Müellif Sufilerinden Kelâbâzînin Oruçla İlgili Yorumları, Ramazan Ve Oruç, (ed. Berat Açıl, Halis Kaya vd.), Haziran 2015, 107-117.

${ }^{42}$ Buhârî, el-Câmi u'ș-șahịh, "Edeb”, 78 (No. 6057). 
kalbi bozukluklar kastedilmiştir. ${ }^{43} \mathrm{O}$ halde bu âyette geçen hastalı neden sadece fiziki hastalıkla sinırlı olsun ki? Yahut âyette emredilen "sıyâm" ile sadece "yeme içme ve cinsel münasebet"ten kaçınmak mı emredilmektedir? "Siyam" kelimesinin Arap dili zenginliği açısından başka anlamları olamaz mı? Veyahut âyette zikredilen "Hilali gördüğünüzde..." ifadesiyle sembolik başka anlamlara neden işaret edilmiş olmasın ki? Kur'ân'ın zahirine aykırı düşmeden, şer'î bir dayanaktan yoksun olmadan ve zâhir anlamı da birinci derece kabul ettikten sonra ${ }^{44}$ oruç âyetlerindeki lafızların işaret edebileceği masadaklardan ibretler, nükteler, fâideler istihraç etmenin ne mahzuru olabilir? Hz. Peygamber (s.a.v.) "Her âyetin bir zâhiri ve bir de bâtını vardır." ${ }^{45}$ dedikten sonra âyetlerin sarih manalarını kabul edip ikinci derecede bâtınî/işâri anlamlar istihraç etmek Said Nursi'nin dediği gibi Kur'ân'in i'câz ve belâgatine hizmet hükmüne geçecektir. ${ }^{46}$ Nitekim konu hakkında çalışması olan Mahmut Ay, Kur'ân'in keyfi ve spekülatif yorumlamalarına karşı müteyakkız olunduktan sonra işârî yorumların faydasını şu şekilde dile getirmiştir:

"Bu yorumlar, Kur'an tefsirinin, salt lafzî/literal anlamın dar hudutlarında kalmaktan kurtulmasına, âyetlerin manalarında farklı ufukların ve derinliklerin keşfedilmesine vesile olabilir. Dolayıstyla zâhirî manaya muhâlif olmay an ve kendisini ona öncelemeyen işâretler, tefsire zenginlik, çok katmanlllk ve hareketlilikgetiren; derinlik kazandıran yorumlar olarak değerlendirilebilir." ${ }^{47}$

Diğer taraftan İbn Acîbe'nin (öl. 1224/1809) dediği gibi, Kur'ân zahir ulemaya zahir bir kitap bâtın olanlara bâtın bir kitaptrı. ${ }^{48}$ Buna örnek olarak Sûfî müfessirlerden Kuşeyrî, (öl. 465/1072) tefsirinin marifet ehlinin dilinden dökülen Kur'ânî işaretler olduğunu ifade etmiştir. ${ }^{49}$ Benzer ifadeleri Ruzbihân Baklî̀de de (öl. 606/1209) görmek mümkündür. O da Allah'in, âyetlerin zâhirî manalarinı ulemaya, gizli latîfe ve sırlarıı "ehl-i safvet" e bahşettiğini ifade etmiştir. ${ }^{50}$ Kâşânî (öl. 736/1335) ise Kur'ân’ okudukça kelimelerin

43 el-Bakara 2/10; el-Enfâl 8/49; et-Tevbe 9/125; el-Ahzâb 33/32; en-Nûr 24/50.

${ }^{44}$ Muhammed Hüseyin Zehebî (öl. 1977) bu şartlar yerine geldikten sonra işârîtefsirlerin serdettikleri manaların makbul olduğunu ifade etmiștir. Zehebî, et-Tefsîr ve'l-mufessirûn, 2/280.

45 İbn Hibbân, Sahîh ìbn Hibbân, 1/276 (No. 75); Ebû Bekr Ahmed b. Amr b. Abdilhâlik el-Bezzâr el-Basrî, Müsnedü'l-Bezzâr, thk. Mahfûzurrahmân Zeynullah (Medine: Mektebetu Ulûm ve'l-Hukm, 1988), 5/441 (No. 2081); Ebü'l-Kāsım Müsnidü'd-dünyâ Süleymân b. Ahmed b. Eyyûb et-Taberânî, el-Mu'cemu'l-kebîr, thk. Hamdî b. Abdulhamîd es-Selefî (Kahire: Mektebetu İbn Teymiye, 1994), 10/105 (No. 10107); Ebû Ca'fer Ahmed b. Muhammed b. Selâme el-Ezdî el-Hacrî el-Mısrî et-Tahâvî, Şerhu müşkili'l-âsâr, thk. Şuayb el-Arnavûd (Beyrut: Muessesetu'r-Risâle, 1415), 8/87 (No. 3077).

46 Said Nursi, Şuâlar (ìstanbul: Envar Neşriyat, 1995), 682.

47 Mahmut Ay, "Işâ̂î Tefsiri Yeniden Düşünmek”, İstanbul Üniversitesi ilahiyat Fakültesi Dergisi 24 (2011), 103.

48 Ebü'l-Abbâs Ahmed b. Muhammed b. Mehdî el-Hasenî eş-Şâzelî, el-Bahrü'l-medîd fi tefsî̀ri'l-Kur'âni'l-mecîd, thk. Ahmed Abdullah el-Kuraşî Raslân (Beyrut: Dâru'l-Kutubi'l-ilmiyye, 2002), 1/49.

49 Ebü'l-Kāsım Zeynülislâm Abdülkerîm b. Hevâzin b. Abdilmelik el-Kuşeyrî, Letâifu'l-işârât, thk. Abdüllatîf Hasen Abdurrahman (Beyrut: Dâru'l-Kutubi'l-i̇lmiyye, 2007), 1/5.

50 Ebû Muhammed Sadrüddîn Rûzbihân b. Ebî Nasr el-Baklî, 'Arẩisü'l-beyân fi hakāi'ik'l-Kur'ân, thk. Ahmed Ferîd Mezî̀î (Beyrut: Dâru'l-Kutubi'l-illmiyye, 2008), 11. 
altında kendisine inkişâf eden/açlan manalardan bahsetmiştir. ${ }^{51}$ Bikâî, (öl. 885/1480) âyetlerin ve sûrelerin birbirleriyle olan münasebetlerine adadığı Nazmu'd-Dürer adlı tefsirini -işâri bir tefsir olarak kabul edilmemesine rağmen- "Allah böyle bir tefsir kalem almaya dair beni teyit etti. ${ }^{" 52}$ demiş ve âyet ve sûrelerin tertibinde işârî manalar olduğu teziyle hareket etmiştir. Hatta Selefi/Hanbeli ekolün önde gelen isimlerinden ve sûfîlerin izlemiş olduğu yöntemi sert bir dille eleştiren İbnü'l-Cevzînin ${ }^{53}$ (öl. 597/1201) dahi tefsirinde işârî manalara yer verdiği görülmektedir. Örneğin o, Fetih sûresinin "Muhammed Allah'in elçisidir. Beraberinde bulunanlar da kâfirlere karşı çetin, kendi aralarında merhametlidirler. Onları rükûya varrrken, secde ederken görürsün. Allah'tan lütuf ve riza isterler." ${ }^{24}$ âyetinde Hülefâ-i Râşidîn'e sırasıyla işaret edildiğini söyleyen Hasan-1 Basrînnin görüşüne yer vermiştir. ${ }^{55}$ Hâlbuki âyetin zâhirinden böyle bir anlam çıkarmak mümkün değildir. Sonuç olarak şunu söylemek îcâb eder ki eğer kişi, zahiri anlamlarıyla iktifa ediyorsa bu onun hakkıdır. Aynen onun gibi tasavvuf erbabının zahiri anlamı inkâr ve ondan teberrî etmedikleri sürece lafız ve münasebetlerden kalplerine akseden işâ̂î nükte ve latifelerle sevinmeleri, ibretlerle meşgul olmaları da onların hakkıdır.

Bu çalışma işârît tefsir olarak bilinen tefsirlerdeki yorumların geçerliliği/sıhhati özelinde bir araştırmayı amaçlamadığı için konu hakkındaki kanaatimizi ifade etme bakımından bu kadarın yeterli olduğunu düşünüyoruz. Burada ayrıca şunu belirtmek gerekir ki işârî/sûfî/bâtınî ünvanları altında Kur'ân'ın ana maksatlarıyla çelişen yahut sahih itikada ters düşen bâtıl yorumların bulunduğu muhakkaktır. ${ }^{56}$ Ancak şu var ki bazı bâtınî yorumların dalâlete varacak derecede yanlış olduğu bir gerçekse de aynı gerçeklik salt literal okuma biçimleri için de geçerlidir. Nitekim Kurân'n bizzat sakındırdığı "fitne uyandırıcı te'vil”"57 ilk olarak Hâricîler tarafından gerçekleşmiş̧tir. K1-

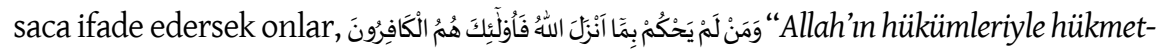
meyenler kâfirlerdir." ${ }^{158}$ âyetinden yola çıkarak Hz. Ali olmak üzere pek çok sahabîyi,

51 Kemâlüddîn Abdürrezzâk b. Ebi'l-Ganâim Muhammed el-Kâşânî, Te’vîlâtü'l-Ḳur'ân (Suudi Arabistan: Melik Suûd Üniversitesi Kütüphanesi, 153), 1.

52 Ebü'l-Hasen Burhânüddîn İbrâhîm b. Ömer b. Hasen er-Rubât el-Hırbevî el-Bikāî, Naẓmü'd-dürer fi tenâsübi'l-âyât ve's-süver (Kahire: Dâru'l-Kitâbi'l-İslâmî, ts.) 1/5.

53 İbnü’l-Cevzî dalalet üzere gördüğü fırkalara reddiyeler sadedinden kalem aldığı Telbîsu İblîs kitabının on üç bâbından bir bâbını yani yaklaşık yüz elli sayfayı tamamen tasavvuf erbabının hatalı bulduğu taraflarına tahsis etmiş ve onları kıyasıya eleştirmiştir. İlgili bölüm için bk. Ebü’l-Ferec Cemâlüddîn Abdurrahmân b. Alî b. Muhammed İbnü'l-Cevzî el-Bağdâdî, Telbîsu íblîs (Beyrut: Dâru'l-Kalem, 1403), 155-320.

54 el-Fetih 48/29.

55 Ebü'l-Ferec Cemâlüddîn Abdurrahmân b. Alî b. Muhammed İbnü'l-Cevzî el-Bağdâdî, Zâdu'l-mesîr, thk. Abdürrezzâk el-Mehdî (Dâru'l-Kitâbi'l-Arabî), 4/138

56 Ayrıntı için bk. Avni İlhan, "Bâtıniyye", Türkiye Diyanet Vakfi İslam Ansiklopedisi (İstanbul: TDV Yayınları, 1992), 5/190-194.

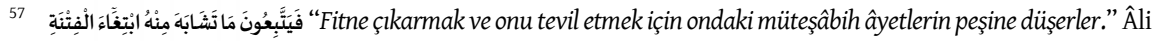
İmrân $3 / 7$.

58 Mâide 5/44. 
tahkimi ${ }^{59}$ kabul etmelerinden dolayı tekfir etmiş ve âyetin lafzını/zahirini doğrudan onlara tatbik ederek büyük bir fitnenin kapısını aralamışlardır. ${ }^{60}$ Diğer taraftan fikıh tarihinde, âyetlerin zâhirî anlamlarını esas alarak İslam'ın temel ilkeleri ile çelişen pek çok yanlış değerlendirmeler yapıldı̆̆ı ve bu yüzden de bu "zâhirî ulemâ"nın "câhil, âmî" şeklinde ithamlara maruz kaldığı bilinmektedir. ${ }^{61}$ Yine âyetlerde geçen haberî sıfatları (يدالهَ Allah'ın eli gibi) olduğu gibi zâhirî anlamlarıyla kabul edip tecsîm ve teşbih denilen sapık görüşlere zehâb eden ya da meyleden kimseler olmuştur. ${ }^{62}$ o halde düşüncede istikamet, zâhir/bâtın meselesi değil usûl meselesidir. Yapılan yorumu yanlış kılan, yorumu yapılan hususa zâhirinden ya da bâtınından bakmak değil bakış biçiminin yanlışlığıdır; usulsüz, ilkesiz, bütünden kopuk, sorumsuz yaklaşımlardır. Zaten şu da bir gerçek ki herhangi bir ilim geleneğine dayanmayan keyfi/başıboş yorumlar zamanla unutulup gitmektedir. Bu itibarla yapılan yorumların hakikatten mesnetsiz oluşu bizzat hakikatin kendisi tarafından deyim yerinde ise cezalandırılacak ve nisyana mahkûm edilecektir.

\section{Oruç Âyetleri Hakkında Belli Başli İşârî Yorumlar}

İşarî tefsir sahibi denildiğinde ilk akla gelen isimlerden olan Kuşeyrî ${ }^{63}$ (465/1072) orucun iki türlü olduğunu ifade etmiştir: Zâhiri ve bâtınî oruç. Zahiri oruç kişinin oruç niyetiyle orucu bozan şeylerden kendini men etmesidir. Bâtıni oruç ise kalbi manevi hastalıklar olan afetlerden korumasıdır. Bundan sonra ruhu "musâkeneler"den ve sırrı da "mülahazalar"dan uzak tutmasıdır. Kuşeyrî burada zahiri oruç için صوم "savm", batıni oruç için ise korumak anlamında صون "savn" kelimesini kullanmıştır. Görüldü̈̆ü gibi “oruç" ve "koruma” için kullanılan kelimeler ses bakımından da birbirleriyle uyum halindedir.

Müfessir orucun mahiyeti ve olgunluğu bakımından âbid ve ârif farkına dikkat çekmektedir. Ona göre âbidlerin orucunun kâmil olması için dilin giybetten, gözün ise haramdan muhafaza edilmesi gerekmektedir. Bunu teyit eden bir habere yer vermiştir: "Kim oruç tutarsa kulağı ve gözü de oruç tutsun.” Bu rivayet müellifin maksadı ile tam örtüşen bir rivayettir. Bundan daha üstün olan oruç ise âriflerin orucudur ki bu da müşahede ettiği şeyleri kendinden başkasından gizlemenin orucudur.

59 Hakem olayı olarak bilinen hadisenin ayrıntısı için bk. İlyas Üzüm, “Sıffin Savaşı”, Türkiye Diyanet Vakfı İslam Ansiklopedisi (İstanbul: TDV Yayınları, 2009), 37/108-109.

60 Ebû Mansûr Abdülkāhir b. Tâhir b. Muhammed et-Temîmî el-Bağdâdî, el-Fark beyne'l-firak, thk. Muhammed Osmân el-Haşin (Kahire: Mektebetu İbn Sînâ, ts.), 72.

61 Ebû Bekr Ahmed b. Alî er-Râzî el-Cessâs, Usûlü'l-fikh, thk. Acîl Câsim en-Neşmî (b.y.: Vizâratu'l-Evkâf, 1994), 3/296.

62 Yusuf Şevki Yavuz, “Müşebbihe”, Türkiye Diyanet Vakfi İslam Ansiklopedisi (İstanbul: TDV Yayınları, 2006), 32/156-158.

63 Müfessir hakkında ayrıntı için bk. Süleyman Uludă̆, "Kuşeyrî, Abdülkerîm b. Hevâzin, Türkiye Diyanet Vakfi İslam Ansiklopedisi (Ankara: TDV Yayınları, 2002), 26/473-475. 
Eğer kişi orucu bozan şeylerden kendini çekerek oruç tutuyorsa bu orucun iftar vakti gecenin gelmesi iledir. Eğer kişi Allah’tan gayrısına (Mâsivâ) karşı oruç tutmuşsa bu orucun sonu Allah'ı müşahede etmesi ile son bulacaktır. Müfessir bu görüşünü “Oruç tutun ve onu görünce de iftar edin." hadisinden istihraç etmektedir. Bilindiği haliyle "onu görünce" ifadesindeki zamir hilale râcîdir. Hâlbuki müellifin ifadesiyle "tahkik ve havas ehli” nezdinde buradaki zamir Allah'a râcîdir. Buna göre hadisin anlamı şöyledir: Onların şuhûdları Allah için, iftarları Allah ile teveccühleri Allah'a, kendilerine gâlib olan Allah ve dertleri Allah'a karşı mahviyyet olduğu için oruçları Allah içindir. ${ }^{64}$

Benzer yorum Bursevî’de de ${ }^{65}$ (öl. 1137/1725) görülmektedir. O da fikıh ilmince belirlenen şeylerden uzak durma anlamındaki bir orucun "avamın orucu" olduğunu ifade etmiştir. Havâs dediği kimselerin orucu ise sadece yeme/içme değil tüm yasaklanan şeylerden uzak durmaktır. Ehassu'l-havâs dediği kimselerin orucu ise Kuşeyrî̀nin de dediği gibi فالامساك عما سوى الله تعالى Allah'in dışındaki her şeye karşı oruç tutmaktır. ${ }^{66}$

Kuşeyrî Arapçada "bâ" ve "lâm" harf-i cerlerinin anlam farklılı̆̆ını kullanarak gayet veciz bir şekilde oruç hakkında uzun ve derin anlamlar ifade etmek istemektedir.

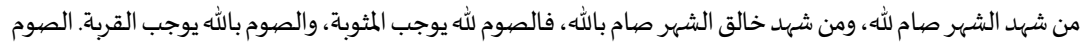

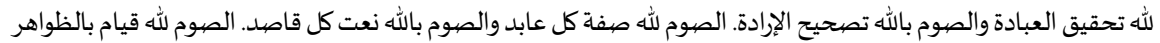

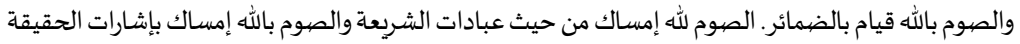

"Kim hilali görürse Allah için oruç tutar. Fakat kim hilalin yaratanın görürse orucu Allah iledir. Allah için tutulan oruç sevap getirir. Allah ile tutulan oruç ise kurbet/yakınlk sebebidir. Allah için oruçla ibadet tahakkuk etmiş olur. Allah ile tutulan oruç ise iradenin tashih edilmesidir. Allah için oruç her âbidin özelliğidir. Allah ile oruç ise her kâsidin sıfatıdır. Allah için oruç zahiri yerine getirerek tutulur. Allah ile oruç ise gizli hallerin tutulmasıyla olur. Allah için oruç şeriatın emrettiği ibadetler açısından tutulur. Allah ile oruç ise hakikat işaretleriyle tutulur."67

Herkes tarafından anlaşılması istenmediği üslubundan aşikâr olan bu ifadelerle Kuşeyrî, Arapçadaki iki harf-i cerrin -"bâ"68 ve "lâm"69- arasındaki delalet farklılığıyla "oruç" ibadetinin derinliğini -müdakkik gözlere- göstermek istemektedir. Müslümanlar Ramazan hilalini gördüklerinde oruca başlar. Hâlbuki gökyüzünde bir gece lambası olan ayı insanlara musahhar kılıp hizmetlerine tahsis eden Allah'ı düşünen kişi, zaten tüm masivâdan gönlünü çekmiş ve her daim Allah'ın tefekkürü ile adeta oruç halindedir. Yani Allah için oruç tutuyor değil Allah'la oruç tutuyordur. Allah'ın

\footnotetext{
${ }^{64}$ Ebü'l-Kāsım Zeynülislâm Abdülkerîm b. Hevâzin b. Abdilmelik el-Kuşeyrî, Letâifu'l-işârât, thk. Abdüllatîf Hasen Abdurrahman (Beyrut: Dâru'l-Kutubi'l-ilmiyye, 2007), 1/87.

65 Bursevî hakkında ayrıntılı bilgi için bk. Ali Namlı, "İsmail Hakkı Bursevî”, Türkiye Diyanet Vakfi İslam Ansiklopedisi (İstanbul: TDV Yayınları, 2001, 23/102-106.

66 İsmail Hakkı Bursevî, Rûhu'l-beyân (Beyrut: Dâru'l-Fikr, ts.), 1/289.

${ }^{67}$ Kuşeyrî, Letâifu'l-işârât, $1 / 87$.

${ }_{68}$ Bu harf-i cerrin burada "musâhabet" anlamı ifade ettiği anlaşılmaktadır.

69 İbaredeki "lâm" harfine "ecliyyet" anlamı yüklendiği görülmektedir.
} 
marifet ve muhabbetine kendini adamıştır. Kişi Allah için oruç tuttuğunda hadisin ifade ettiği gibi hesapsız bir sevaba nail olacaktır. Fakat kişi Allah'ın muhabbetiyle kendinden geçerek O'nun varlığı ile oruç tutuyorsa nail olacağı sadece sevap değil, bunun da ötesinde O'nun yakınlığını tadacaktır. Oruç tutmakla ibadet yerine gelmiş olmaktadır. Fakat kişi Allah ile oruç tuttuğunda kendi iradesi, isteği ve arzusundan sıyrılarak iradesini tamamen Allah'ın iradesine bırakmış ve yani O'nda fani olmuştur. Oruç ibadetinin bir zahiri vardır: Yemek içmek ve şehevi arzuları bırakmak gibi görünür halleri terk etmektir. Bu ibadetin bir de Allah'la olanı vardır ki bu oruçta kişi, hiçbir beşerî gözün göremediği vicdânî derinliklerde olan biten sırlı, gizli ahvali terk eder. Oruç ibadetinin fikhîşartları vardır. Başlama ve bitirme zamanı, orucu bozan haller gibi. Bunlar ibadetin zahirine taalluk eden ve tabi ki riayet edilmesi gereken kurallardır. Fakat Allah'la tutulan oruçta bu zahiri şartlar ve kayıtlardan öte kurallar vardır ki bunlar işârî manalarla, tecellilerle belirlenir. Belki de bu esrarengiz kurallar kişiden kişiye değișen hatta anbean farklılık arz eden rengârenk haldedir yahut tondadır. Bunlar الصوم بالله "Allah ile oruç tutmak" ifadesinden anlayabildiğimiz manalardır. Fakat adı üzerinde, bu “işârî” tefsiriyle Kuşeyrî çok daha farklı medlûllere işaret etmiş olabilir.

Kâşânî, ${ }^{70}$ tefsirinde oruçla ilgili olan âyeti, birkaç ayet önceki kısas âyeti ile

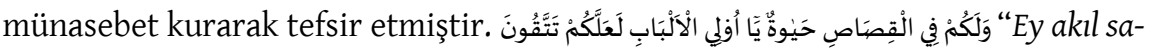
hibleri! Kısasta sizin için hayat vardır. Artık, Allah'a karşı gelmekten sakınırsınız." "11 âyeti mucibince nasıl ki kısas insanlar arasında adaleti tesis etmek için kişinin behîmî kuvvetlerini dizginleyip zulümlerden muhafaza etmektedir; aynı onun gibi oruç da kişideki nefsi ve şehvânî temayülatı kırıp adalete boynunu eğdirmek için diğer bir ilahi kanundur. Anlaşılan Kâşânî'nin bu yorumu Hz. Peygamber'in (s.a.v.) "Oruç kalkandır/zırhtır." hadisinden ilham almıştır. ${ }^{72}$ Bu yoruma göre kısas ve oruç ayetlerinin peş peşe gelmesinde bu şekilde bir anlam münasebeti bulunmaktadır. Bu itibarla buradaki yorumun, ilm-i münasebet kapsamında değerlendirilmesi ve ona bir örnek kabul edilmesi mümkündür. Bir tefsir kavramı olarak münâsebâtü'l-âyât ve's-süver, âyetler ve sûreler arasında sistematik ilişkiler bulunduğu ${ }^{73}$ düşüncesinden hareketle ortaya çıkmış ve tefsir otoriteleri tarafından genel kabule mazhar olmuş bir ilimdir.

Diğer taraftan müfessir orucun işlevselliğini şu şekilde yorumlamıştır: وصيامهم هو الإمساك عن كلّ قول وفعل وحركة وسكون ليس بالحق للحق "Onların orucu Hakk üzere ve Hakk için olmayan her söz, fiil, hareket ve sükûnu terk etmektir." "74

\footnotetext{
70 Müellif hakkında bilgi için bk. Süleyman Uludağ, "Kâşânî, Abdürrezzâk”, Türkiye Diyanet Vakfi İslam Ansiklopedisi (Ankara: TDV Yayınları, 2002), 25/5-6.

71 el-Bakara 2/179.

72 Ahmed b. Hanbel, Müsnedu Ahmed b. Hanbel, 15/446.

73 M. Faik Yılmaz, “Münâsebâtü'l-âyât ve's-süver”, Türkiye Diyanet Vakfi İslam Ansiklopedisi (İstanbul: TDV Yayınlar1, 2006), 31/ 569.

74 Kemâlüddîn Abdürrezzâk b. Ebi'l-Ganâim Muhammed el-Kâşânî, Te’vîlâtü'l-Kur'ân (Suudi Arabistan: Melik Suûd Üniversitesi Kütüphanesi,153), 85b.
} 
Tefsirinde yer yer işârî yorumlara değinen ${ }^{75}$ Sa $^{4} l e b \hat{i}^{76}$ (öl. 427/1035) oruç âyetinin başı olan "Ey iman edenler" ifadesindeki münâda ifade eden "ي” harfine dair Caferi Sadık'a nispet ettiği şu yoruma yer vermiştir: Hitapta yer alan bu nida harfindeki lezzet ibadetteki meşakkati ortadan kaldırmıştır. ${ }^{77}$ Bu yoruma göre Allah'ın kulunu muhatap alarak ona nidada bulunması ve ondan herhangi bir emrinin yerine getirmesini talep etmesindeki şeref ve yücelik ibadetten hâsll olacak külfet ve zahmeti hiçe indirecek keyfiyette bir lezzettir. Buna göre; oruç ibadeti her ne kadar tüm gün boyunca yeme içme gibi zaruri ihtiyaçlardan el çekmeyi ve dolayısıyla da açlık, susuzluk ve bitkinlik gibi zahmet ve meşakkati beraberinde getirse de netice itibariyle Allah'ın emrine, hitabına mazhar bir kul olmanın da lezzeti olacaktır.

Cafer-i Sâdık'tan aktarılan diğer bir yorum ise Ramazan ayının her bir gününün bir diğerinden farklı bir basamak olduğunu şu şekilde ifade etmiştir:

"Sâdık der ki: Allah, ramazan orucunu emretmesiyle, bize şu sırrı ikram etmiştir: Bizim önümüzde cehennem, firâk, azil ve benzeri otuz yokuş ve engel olduğu için Ramazan da otuz gündür. Kim oruç tutarsa Allah onu, o engellerden kurtarı; vuslat, inâbe ve rü’yet gibi otuz menzile; mülk ile birlikte cennete; Mustafâ (s.a.v.) ile beraber velâyete ulaştırır. Oruç bize bu hikmet için farz kılınmıştır." ${ }^{78}$

Bursevî, كتب عليكم الصيام “Size oruç farz kılındı” âyetine muhatap olan nesnenin işârî manası olarak; "Müslüman'ın maddi ve manevi uzuvları ihtiva eden bedeni” olduğunu söylemektedir. Bu yoruma göre, insanın fiziki organları ve manevi duyguları bu âyetin muhatabıdır. Dolayısıyla buradan hareketle dilin orucu; yalan, fuhşiyat ve gıybetten uzak durmaktır. Gözün orucu ise gaflet ve şüphe halinde görmemektir. Kulağın orucu ise nehyedilen şeylere karşı kulağı tıkamaktır. Nefsin orucu geleceğe dair ümitleri, hırs ve şehveti dizginlemektir. Kalbin de orucu vardır. Onun orucu dünyanın ziynet ve sevgisine karşı yüz çevirmektir. Ruhunki ise ahiretin lezzet ve nimetlerine talip olmamaktır. Sırrın orucu Allah'ın gayrısının vücudunu görmek ve onlara bir vücut vermekten imtina etmesidir. ${ }^{79}$ Bu yoruma göre bir insan her ne kadar tek bir "fert/birey" gibi görünse de emanet olarak taşıdığı muhtelif bedenî ve ruhî uzuvları ile büyük bir âleme nezaret etmekte ve bu suretle çok fertleri ihtivâ eden bir câmi’ gibi olmaktadır. ${ }^{80}$

75 Süleyman Uludağ, “işsari Tefsir”, Türkiye Diyanet Vakfi İslam Ansiklopedisi (istanbul: TDV Yayınları, 2001), 23/424-428.

76 Müellif hakkında ayrıntı bilgi için bk. M. Suat Mertoğlu, "Sa'lebî”, Türkiye Diyanet Vakfi İslam Ansiklopedisi (istanbul: TDV Yayınları, 2009), 36/28-29.

77 Ebû İshâk Ahmed b. Muhammed b. İbrâhîm es-Sa'lebî en-Nîsâbûrî, el-Keşfve'l-beyân 'an tefsîri'l-Kur'ân, thk. Ebû Muhammed b. Âşûr (Beyrut: Dâru İhyâi't-Turâsi'l-Arabî, 2002), 2/61

78 Yunus Emre Gördük, İmam Cafer es-Sâdık ve Ona İsnad edilen İsari Tefsir (İstanbul: İnsan Yayınları, 2011), 224.

79 Bursevî, Rûhu'l-beyân, 1/292

80 Oruç hakkındaki bu işâri yorum hemen hemen benzer bir yaklaşımla Said Nursi'de de göze çarpmaktadır. $O$ da orucun mükemmel olan halinin yukarıdaki tefsirlerde izah edildiği şekliyle olabileceği vurgusunda bulunmaktadır. "Ve o orucun ekmeli ise, mide gibi bütün duyguları, gözü, kulağı, kalbi, hayali, fikri gibi cihazat-ı insaniyeye dahi bir nev'î oruç tutturmaktır. Yani, muharremattan, 


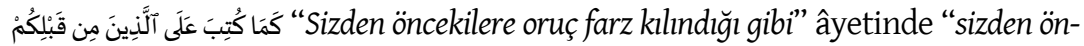
cekiler" ile kastedilen sarih mana, Yahudi ve Hiristiyanlar gibi kitap ehli kimselerdir. Tefsirlerin belirttiğine göre oruç, şekli ve müddeti farklı olsa da önceki semavi dinlerde de mevcuttu. İşari tefsirin simge isimlerinden olan Necmeddîn-i Dâye, (öl.

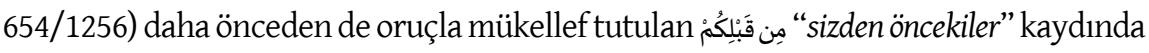
epey ilginç bir yorumda bulunmaktadır. Bu yoruma göre "öncekiler" ile sadece ehl-i kitap değil, insanın bir beşer haline gelmeden önceki zerreleri de kastedilmiştir. Ruhani ve cismani eczasiyla bir araya gelerek bir bütün halinde "Insan" olan bu beşerî varlık, gözümüz önündeki bu terkibe kavuşmadan önce de zerreler âleminde iken müellifin ifadesiyle- tüm "meşârib" denilen nimetlerden mahrumdu. İnsan bedeninin terekküp ettiği zerreler yeme, içme gibi beşerî ihtiyaçlardan azade bir surette âdeta oruç tutmakta idiler. Ne vakit ruh bedene girdiği ve cism-i beşerî teşekkül ettiğinde bedenin eczası, ruhun imdâda yetişmesi nispetinde hayvani ve ruhani hazlardan istifade eder hale gelir. ${ }^{81}$ Bu suretle zerreler âleminde iken oruçlu olan ecza-i beden, nefh-i ruh ezanı ile sanki iftar etmiş ve maddi manevi lezzetlerden yararlanır

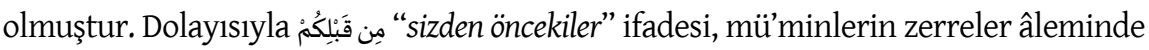
iken bazı nimetlerden mahrum -oruçlu- hallerini zihinde tasvir etmeye dair bir ihtarı ihtiva etmektedir. Buna göre âyette, insan suretine gelinceye kadarki beşerî ahval ve etvâr içerisinde ihsan edilmiş nimetleri hatırlatmaya yönelik bir işaret bulunduğu anlaşılmaktadır.

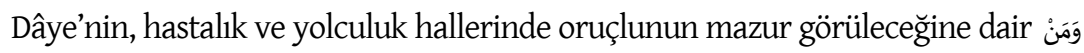

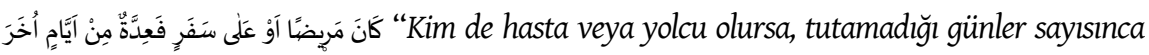
başka günlerde tutsun"82 âyetine getirdiği işari yorumlar da oldukça dikkat çekicidir. Tasavvufçuların dilinde, "kâmil insan olma yolunda bir mürşidin gözetiminde yapılan manevi yolculuk" anlamına gelen seyr u sülûka ${ }^{83}$, Dâye'ye göre mezkûr âyette vârid olan "sefer" lafzıyla işaret edilmektedir. Diğer taraftan kalbe arız olan nefsin galebelerine âyette geçen "maraz/hastalk" ile işarette bulunulmuştur. Sefer ve maraz lafizlarına işârî olarak yüklenen delalete göre âyet, şu anlamları da ifade etmektedir:

"Eğer kişi, kalbine nefsin sıfatları, beşeriyetin muktezaları ve tabiatının tembelliğinin galebesinden kaynaklanan bir hastalkla seyr u sülûkunda bir gevşeklik gösterir de kalbin hudut-

mâlâyâniyattan çekmek ve herbirisine mahsus ubudiyete sevk etmektir. Meselâ, dilini yalandan, giybetten ve galiz tabirlerden ayırmakla ona oruç tutturmak ve o lisanı, tilâvet-i Kur'ân ve zikir ve tesbih ve salâvat ve istiğfar gibi şeylerle meşgul etmek; meselâ gözünü nâmahreme bakmaktan ve kulağını fena şeyleri işitmekten men edip, gözünü ibrete ve kulağını hak söz ve Kur'ân dinlemeye sarf etmek gibi, sair cihazata da bir nev'î oruç tutturmaktır. Said Nursi, Mektubat (İstanbul: Envar Neşriyat, 2003), 402-403.

81 Ebû Bekr Necmüddîn-i Dâye, et-Te'vîlâtün-Necmiyye, tah. Ahmed Ferîd el-Mezîlî (Beyrut: Dâru'l-Kutubi'lilmiyye, 2009), 1/260.

82 el-Bakara 2/185.

83 Süleyman Uludağ, "Sülûk", Türkiye Diyanet Vakfi İslam Ansiklopedisi (İstanbul: TDV Yayınları, 2010), $38 / 127$. 
ları dışına inhiraf ederse veyahut sülûku esnasında hakikatin ahkâmının yüklerini omuzlamaktan acizliğe düşerse iradesi şiddet kesbedip cesareti kuvvet buluncaya, inayet-i ilahiye ona yetişip hastalğını lütfunun macunları ve ilaçlarıyla tedavi edinceye kadar kendine mühlet ver$\sin { }^{84}$

Dâye'nin âyetten aldığı ilhamla yapmış olduğu bu yoruma göre kişi, manevi yolculuğunda zaman zaman sekteye ve fütura kapılabilir; şevkini kaybedip beşeriyet muktezası gevşekliklere düşebilir. Hakikat peşinde taharride bulunurken kimi zaman uğradığı makamların ağırlığından yorulup acizlik gösterebilir. Bu takdirde ona düşen, inayet imdadına yetişinceye kadar duçar olduğu fütur haleti karşısında sabır göstermesi ve yolculuğunda bir müddet istirahate çekilmesidir. Kalbi selamete erdiği ve maruz kaldığ marazi haller zeval bulduğunda geçmişte eda edemediği yahut geri kaldığı yolculuğuna sâlik devam edebilir; geçmişin telafisini yapabilir. Müfessirin yapmış olduğu bu yorum aslında sadece tasavvuf erbabı için değil tüm mü’minler açısından da istikamet vericidir denilebilir. Zira kâmil bir Müslüman olma yolculuğu son nefese kadar devam edecek engebeli bir seferdir. Yükseliş ve alçalışlarla, manevi hastalık ve acizliklerle çevrili hakikat yolculuğu elbette tekdüze değildir. O halde yukarıda işaret edildiği gibi mü’min şevk ve zevk üzere ferahlı olduğu vakitlerde nafilelerle meşgul olup firsatı değerlendirmeli, hakikat denizinde küreklere var gücüyle asılmalıdır. Lakin tam aksine, fütur ve manevi hastalıklara maruz kaldığında da yese kapılmamalı, inayet yardımına yetişip şifa buluncaya kadar farzlara kanaat etmelidir.

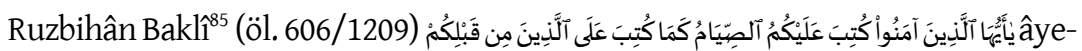
tindeki hitabın ehl-i kalbe ve gayb semâlarının afakında "müşahede" hilalinin peşine düşenlere olduğunu ifade etmiştir. Bu hitaba göre mana şöyledir: Ey yakîn ehli! Siz Allah'in müşahedesini istediğiniz için sizin tüm kâinata karşı bir oruç tutmanız size farz kılınmıştır. Öyle ise sizden önce peygamberlere, ariflere ve âşıklara farz kılındığı gibi makam-ı ubudiyette tabiatın melufatından oruç tutmanız vacip olmuştur. Ta ki insanliğın pisliğinden halas bulasinız, emn ve kurbet makamina eresiniz. ${ }^{86}$

Âyette geçen "hilâl”in sembolik anlamının Allah'ın zatı olduğunu düşünen Baklîye göre Allah'ı müşahede eden kimseler, artık Allah'ın dışındaki tüm varlığı ifade eden mâsivâdan vazgeçmeli yani bir nevi oruç tutmalıdırlar. Kişi oruç tuttuğunda nefsinin hayvani arzularından kurtulduğu gibi gaybi âlemlerin ufkunda Allah'ın müşahedesine nâil olan arif ve sâlikler de insan oluşun necasetlerinden uzaklaşacaklardır. Baklî bir bakıma insanların Allah'tan uzak oldukları için tedirgin, huzursuz ve korku içinde yaşadıklarını, ancak Allah'ın yakınlığı ile itminan ve emniyete ereceklerini ifade etmektedir. Buradan hareketle Ramazan ayında oruç tutan Müslümanların bambaşka bir huzur ve tarifi mümkün olmayan bir sükûnet hissetmeleri kalpleri ile farkında olmadan Allah'ın müşahedesine mazhar olmalarındandır denilebilir.

\footnotetext{
84 Necmüddîn-i Dâye, et-Te’vîlâtün-Necmiyye, 1/261.

85 Müfessir hakkında ayrıntı için bk. Nazif Hoca, "Baklî”, Türkiye Diyanet Vakfi İslam Ansiklopedisi (İstanbul: TDV Yayınları, 1991), 4/545-547.

${ }^{86}$ Baklî, 'Arâ'isü'l-beyân fì hakā'ikı'l-Kur'ân, 75.
} 
"Hilâlin şuhûdu/görülmesi" zâhirinde işarî anlamlar olduğunu düşünen diğer

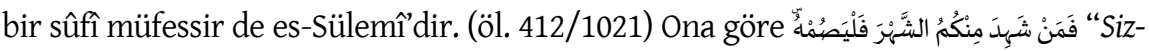
den kim Ramazan ayına yetişirse onda oruç tutsun." ${ }^{\text {"87 }}$ âyetinde kastedilmiş olan zaman dilimi, yılın aylarından sadece bir ayı değildir. Allah'ın emrine şahitlik eden kişi, tüm ömrü boyunca tamamen oruç tutmalıdır. Bu oruçtan müfessirin kastettiği tabi ki ıstılahtaki oruç değildir. O, bir ömür boyu "Allah'n emirlerine muhalefet etmeyi terk etmek" anlamında bir savm/oruç manasına işaret edildiğini düşünmektedir. ${ }^{88}$

Bakara sûresi 184. âyet أياما معدودات "sayllı günler" ifadesiyle başlamaktadır. Tefsirlerin belirttiğine göre bu ifade, oruçla mükellef tutulan mü'minlere teselli vermek maksatlıdır. Ramazan günlerinin senede sadece bir ay olduğunu ve oruçla geçen bu sürenin de "sayll günler" ihtiva ettiğini belirterek orucun külfetinin hafif ve geçici olduğunu haber vermektedir. ${ }^{89} \mathrm{Bu}$ ifade âyetlerden işârî manaları istihraç eden tasavvuf erbabı müfessirler tarafından aynı bağlamda fakat farklı bakış açıları ile tefsir edilmiştir. Ruzbihân Baklî, Ramazan orucunun manasını terk-i masivaya yorduğu için "sayılı günler" ifadesine de bu manayı teyit edecek bir șekilde "dünya hayatı" anlamı yüklemiştir. Allah'ın veli kulları hayatı bir bütün halinde Ramazan gibi yaşayarak helal dahi olsa dünyevi arzuların bütününe yüz çevirmelidir. Kadınlarla münasebetinden yeme içme keyfine hatta güzel kıyafetler giyinme arzusuna kadar her şey fanidir. Ömür "sayıll günler"den ibaret ise veli kullar, zaten gelip geçici bu heveslerin peşinde orucunu bozmamal, nefsini dizginlemesini bilmelidir. ${ }^{90}$

"Sayll günler" ifadesinde Necmeddîn-i Dâye ${ }^{91}$ şöyle bir işaret bulunduğunu ifade etmiştir: Tuttuğunuz oruç sayll ve sinırl günlerdedir. Hâlbuki orucunuzun semere ve faydaları sonsuz ve sayllamayacak kadar uzun bir ebedi hayatta karşıııza çıkacaktır. ${ }^{92}$

\section{Sonuç}

Bu çalışmada "bâtınî" yorumların öne çıkmasından dolayı "işârî" olarak nitelendirilen ve Müslümanlar tarafindan genel anlamda kabule mazhariyeti bilinen tefsirlerin Ramazan ve oruç ibadeti hakkındaki yorumları incelenmiștir. Gördüğümüz kadarıyla bu tefsirler Ramazan hilalini görme, oruçlu iken hastalanma ve sefere çıkma, oruç tutamayınca fidye ödeme vb. hususların zahirî anlamlarının ötesinde simgesel delâletleri bulunduğuna kâildirler. Yorumların çoğu birbirinin tekrarı olsa da bir sonra gelen bir önce gelenden bir şeyler almış ve üzerine kendi yorumlarını da eklemiştir. Bu itibarla tarihi olarak bize en yakın olan Bursevînnin Rûhu'l-beyân tefsiri,

87 el-Bakara 2/185.

88 Muhammed b. Hüseyin es-Sülemî, Hakâiku't-tefsîr, thk. Seyyid Umrân (Beyrut: Dâru'l-Kutubi'l-illmiyye, 2001), 80.

89 Ebû Abdillâh (Ebü'l-Fazl) Fahrüddîn Muhammed b. Ömer b. Hüseyn er-Râzî et-Taberistânî, Mefâtihu'lgayb (Beyrut: Dâru İhyâi't-Turâsi'l-Arabî, 1420), 5/242.

90 el-Baklî, 'Arâ'isü'l-beyân fî hakā'ikı'l-Kur'ân, 75.

91 Müellif hakkında ayrıntı için bk. Mehmet Okuyan, "Necmeddîn-i Dâye”, Türkiye Diyanet Vakfi İslam Ansiklopedisi (İstanbul: TDV Yayınları, 2006), 32/496-497.

92 Necmüddîn-i Dâye, et-Te'vîlâtün-Necmiyye, 1/260. 
işârî tefsirler içerisinde bu türden yorumların bir araya getirildiği en kapsamlı eser olarak kabul edilebilir. Zira gördüğümüz kadarıyla "Oruç” yorumlarında böyle olmuş, kendinden önceki muhtelif yorumları derlemiştir. Diğer taraftan bugün Müslümanlar arasında Ramazan ve oruç hakkında söylenen özlü sözler ve ibret dolu anlatıların bir kısmının kaynağının bu işârî tefsirlerde geçen yorumlar olması büyük olasılıktır. Dolayısıyla anlama derinlik ve etki gücü katan bu yorumlarla Ramazan ve oruç ibadetinin aç kalmanın ötesinde derûnî manaları ihtiva ettiği gerçeğinin pekiştirilmiş olduğu kanaatimizdir. Çalışmanın diğer alan araştırmacılarına bir tavsiyesi de olacaktır. O da işârî tefsirlerdeki belirli bir konu bağlamında bir araya getirilecek yorumlarla müstakil çalışmalar yapılması hususudur. Zira özellikle genel okuyucunun ilgisini çekecek -fikh-1 bâtın- sadedinde nice etkileyici yorumlar bu tefsirlerde serpiştirilmiş bir haldedir. Bunların belirli bir konu başlı̆̆ altında derlenip izahlarının yapılmasının, hassaten son zamanlarda muzdarip olduğumuz ahlaki yozlaşma karşısında faydalı olacağı kanaatindeyiz.

Etik Beyan / Ethical Statement

Yazar / Author
Bu çalışmanın hazırlanma sürecinde bilimsel ve etik ilkelere uyulduğu ve yararlanılan tüm çalışmaların kaynakçada belirtildiği beyan olunur/It is declared that scientific and ethical principles have been followed while carrying out and writing this study and that all the sources used have been properly cited.

Adnan Arslan

\section{Kaynakça}

Abduluyâsevî, Meşân Suûd. et-Tefsîru'l-işârî mâhiyyetuhû ve davâbiduhû. Beyrut: Dâru'l-Kutubîllİlmiyye, 2013.

Ahmed b. Hanbel. el-Müsned. thk. Şuayb el-Arnavûd. 50 Cilt. Beyrut: Muessesetu'r-Risâle, 2001. Askalânî, Ebü'l-Fazl Şihâbüddîn Ahmed. Fethu'l-Bârî. thk. Abdülkâdir Şeybe el-Hamed. 13 Cilt. Riyâd: Mektebetu'l-Melik Fahd, 1421.

Ateş, Süleyman. İ̧̧ârî Tefsir Okulu. Ankara: Ankara Üniversitesi İlahiyat Fakültesi Yayınları, 1974. Ay, Mahmut. "İşârî Tefsiri Yeniden Düşünmek”. İstanbul Üniversitesi İlahiyat Fakültesi Dergisi 24 (2011), 103-148.

Bağdâdî, Ebû Mansûr Abdülkāhir b. Tâhir. el-Fark beyne'l-firak. thk. Muhammed Osmân el-Haşin. Kahire: Mektebetu İbn Sînâ, ts.

Baklî, Rûzbihân b. Ebî Nasr. 'Arâ'isü'l-beyân fi hakā’ikı'l-Ḳur'ân. thk. Ahmed Ferîd Mezîdî. 3 Cilt. Beyrut: Dâru'l-Kutubi'l-ilmiyye, 2008.

Beyhâkî, Ebû Bekr. Şuabu'l-îmân. thk. Abdulalî Abdulhamîd. 14 Cilt. Bombai: Mektebetu'r-Ruşd, 2003.

Bezzâr, Ebû Bekr Ahmed b. Amr. Müsnedü'l-Bezzâr. thk. Mahfûzurrahmân Zeynullah. 20 Cilt. Medine: Mektebetu Ulûm ve'l-Hukm, 1988.

Bikāî, Burhânüddîn İbrâhîm. Naẓmü'd-dürer fi tenâsübi'l-âyât ve's-süver. 22 Cilt. Kahire: Dâru'lKitâbi'l-İslâmî, ts. 
Buhârî, Muhammed b. İsmail. el-Câmi'u'ș-ṣahîh. nşr. Muhammed Züheyr b. Nasr. 9 Cilt. b.y.: Dâru Tavki'n-Necât, 1422/2001.

Bursevî, İsmail Hakkı. Rûhu'l-beyân. 11 Cilt. Beyrut: Dâru'l-Fikr, ts.

Cessâs, Ebû Bekr Ahmed b. Alî er-Râzî. Usûlü'l-fikh. thk. Acîl Câsim en-Neşmî. 5 Cilt. b.y.: Vizâratu'l-Evkâf. 1994.

Çelebi, İlyas. “Ezeliyet”. Türkiye Diyanet Vakfi İslam Ansiklopedisi. EK-1/431-432. İstanbul:TDV Yayınları, 2016.

Çiçek, M. Halil. “Kur'ân'da Anlam Zenginliği”. Kur'an Araştırmaları Sempozyumu (İstanbul: 2008). 21-46.

Dârekutnî, Ebü'l-Hasen Alî b. Ömer b. Ahmed. Sunenu Dârekutnî. thk. Şuayb Arnavûd. 3 Cilt. Beyrut: Muesesetu'r-Risâle, 2004.

Demir, Recep. "Diğer İnanç Sistemlerinde ve İslâmda Oruç (Karşılaştırmalı Bir Analiz)". Uluslararası Sosyal Araştırmalar Dergisi 9/42 (Şubat 2016), 1784-1799. https://doi.org/ 10.17719/jisr.20164 216287

Dönmez, İbrahim Kâfi. "Oruç". Türkiye Diyanet Vakfi İslam Ansiklopedisi. 33/416-425. İstanbul: TDV Yayınları, 2007.

İbn Hibbân, Ebû Hâtim Muhammed b. Ahmed. Sahîh İbn Hibbân. thk. Şuayb el-Arnavûd. 9 Cilt. Beyrut: Muesesetu'r-Risâle, 1988. https://doi.org/10.1163/_eifo_sim_3199

Râzî, Fahreddîn Muhammed b. Ömer. Mefâtihu'l-gayb. 32 Cilt. Beyrut: Dâru İhyâi't-Turâsi'l-Arabî, 1420.

Gördük, Yunus Emre. Tarihsel ve Metodolojik Açıdan İşârî Tefsir. İnsan Yayınları, İstanbul 2012.

Gördük, Yunus Emre. “Tefsir-Te'vîl Ayrımı Ve İşârîTefsirin Öznel Mahiyeti Bağlamında YorumAlg1" Sorunu". Pamukkale Üniversitesi İlahiyat Fakültesi Dergisi 4/7 (Mart 2017), 1-27. https://doi.org/10.17859/pauifd.293263

Gördük, Yunus Emre. İmam Cafer es-Sâdık ve Ona İsnad edilen İşârî Tefsir. İstanbul: İnsan Yayınları, 2011.

Hasen b. Alevî, Muhammed b. Abbâs b. Abdilazîz. Ebvâbu'-ferac. Beyrut: Dâru'l-Kutubi'l-İlmiyye, ts.

Haydar, Hâzim Saîd. Ulûmu'l-Kur'ân beyne'l-burhân ve'l-itkân dirâsetun mukârane. Medine: Dâru'zZamân, 1420.

Hoca, Nazif. "Baklî”. Türkiye Diyanet Vakfi İslam Ansiklopedisi. 4/545-547. İstanbul: TDV Yayınları, 1991.

Hudayrî, Muhammed b. Abdullah b. Alî. Tefsîru't-tâbiîn. 2 Cilt. Dâru'l-Vatan li'n-Neşr, ts.

Itr, Nûreddîn. Ulûmu'l-Kur'âni'l-Kerîm. Şam: Matbaatu's-Sabâh, 1993.

İbn Acîbe, Ebü'l-Abbâs Ahmed b. Muhammed. el-Bahrü'l-medîd fi tefsîri'l-Kur âni'l-mecîd. thk. Ahmed Abdullah el-Kuraşî Raslân. 6 Cilt. Beyrut: Dâru'l-kutubi'l-ílmiyye, 2002.

İbn Ebî Şeybe, Ebû Bekr. Musannef İbn Ebî Şeybe, thk. Kemâl Yûsuf el-Hût. 16 Cilt. Riyâd: Mektebetu'r-Ruşd, 1409), 4/214 (No. 19418).

İbn Fûrek, Ebû Bekr Muhammed b. el-Hasen. Tefsiru'l-Kur'ân. İstanbul: Millet Kütüphanesi, Feyzullah Efendi Bölümü, 50.

İbn Mâce, Ebû Abdillâh Muhammed. Sunenu İbn Mâce. thk. Muhammed Fuâd Abdülbâkî. Kâhire: Dâru İhyâi'l-Kutubi'l-Arabiyye, ts.

İbnü'l-Cevzî, Ebü'l-Ferec Cemâlüddîn Abdurrahmân. Zâdu'l-mesîr. thk. Abdürrezzâk el-Mehdî. Beyrut: Dâru'l-Kitâbi'l-Arabî, 1422.

İbnü'l-Cevzî, Ebü'l-Ferec Cemâlüddîn Abdurrahmân. Telbîsu İblîs. Beyrut: Dâru'l-Kalem, 1403.

İlhan, Avni. "Bâtıniyye". Türkiye Diyanet Vakfi İslam Ansiklopedisi". 5/190-194. İstanbul: TDV Yayınları, 1992.

Karasakal, Şaban. Kur’ân'ın İşârî Yorumu. İstanbul: Rağbet Yayınları, 2016. 
Kâşânî, Kemâlüddîn Abdürrezzâk b. Ebi'l-Ganâim Muhammed. Te’vîlâtü'l-Kưưân. Suudi Arabistan: Melik Suûd Üniversitesi Kütüphanesi, 153 ق 85b.

Kattân, Mennâ'. Mebâhisun fí Ulûmi'l-Kur'ân. Kahire: Mektebetu Vehbe, ts.

Kuşeyrî, Abdülkerîm b. Hevâzin b. Abdilmelik. Letâifu'lişârât. thk. Abdüllatîf Hasen Abdurrahman. 3 Cilt. Beyrut: Dâru'l-Kutubi'l-İlmiyye, 2007.

Mertoğlu, M. Suat. “Sa’lebî”. Türkiye Diyanet Vakfi İslam Ansiklopedisi. 36/28-29. İstanbul:TDV Yayınları, 2009.

Naml, Ali. “İsmail Hakkı Bursevî”. Türkiye Diyanet Vakfi İslam Ansiklopedisi. 23/102-106. İstanbul: TDV Yayınları, 2001.

Namlı, Tuncer. "Fikıhçıların Allah Algısı -Namaz Örneği-“. Eskiyeni 32 (Bahar 2016), 55-72.

Necmüddîn-i Dâye, Ebû Bekr. et-Te'vîlâtün-Necmiyye. tah. Ahmed Ferîd el-Mezîdî. 6 Cilt. Beyrut: Dâru'l-Kutubi'l-illmiyye, 2009.

Nesefî, Ebû Hafs Necmüddîn Ömer. el-Akâidu'n-Nesefiyye. Suudi Arabistan: Melik Suûd Üniversitesi Kütüphanesi, 213 ن.

Nursi, Said. Mektubat. İstanbul: Envar Neşriyat, 2003.

Nursi, Said. Şuâlar. İstanbul: Envar Neşriyat, 1995.

Okuyan, Mehmet. "Necmeddîn-i Dâye”. Türkiye Diyanet Vakfi İslam Ansiklopedisi. 32/496-497. İstanbul: TDV Yayınları, 2006.

Rummânî, Ebü'l-Hasen Alî b. Îsâ. Tefsîru Ebi'l-Hasen er-Rummânî. thk. Hıdr Muhammed Nebhâ. Beyrut: Dâru'l-Kutubi'l-İlmiyye, ts.

Sa'lebî, Ebû İshâk Ahmed b. Muhammed. el-Keşf ve'l-beyân 'an tefsiri'l-Kur'ân. thk. Ebû Muhammed b. Âşûr. 10 Cilt. Beyrut: Dâru İhyâi't-Turâsi'l-Arabî, 2002.

Sarıcaoğlu, Mustafa. “ibadetler Bağlamında Zâhirî ve Bâtınî Fıkıh: Gazzâlî Örneği”. İslam Bilimleri Araștırmaları Dergisi 5 (2018), 6-32.

Sülemî, Muhammed b. Hüseyin. Hakâiku't-tefsîr. thk. Seyyid Umrân. Beyrut: Dâru'l-Kutubi'l-illmiyye, 2001.

Taberânî, Ebü'l-Kāsım Müsnidü'd-Dünyâ. el-Mu'cemu'l-evsat. thk. Tarık b. ivadullah b. Muhammed. 10 Cilt. Kahire: Dâru'l-Harameyn, ts.

Taberânî, Ebü'l-Kāsım Müsnidü'd-Dünyâ. el-Mu'cemu'l-kebîr. thk. Hamdî b. Abdulhamîd es-Selefî. 25 Cilt. Kahire: Mektebetu İbn Teymiye, 1994.

Tahâvî, Ebû Ca'fer Ahmed b. Muhammed. Şerhu müşkili'l-âsâr, thk. Şuayb el-Arnavûd. 16 Cilt. Beyrut: Muesesetu'r-Risâle, 1415.

Türer, Osman. "Tasavvufi Düşüncede İnsan”. Tasavvuf ilmi ve Akademik Araştırma Dergisi (2001), 9-15.

Uludağ, Süleyman. “İşârî Tefsir”. Türkiye Diyanet Vakfi İslam Ansiklopedisi. 23/424-428. İstanbul: TDV Yayınları, 2001.

Uludağ, Süleyman. "Kâşânî, Abdürrezzâk". Türkiye Diyanet Vakfi İlam Ansiklopedisi. 25/5-6. Ankara: TDV Yayınları, 2002.

Uludă̆, Süleyman. "Kuşeyrî, Abdülkerîm b. Hevâzin, Türkiye Diyanet Vakfi İslam Ansiklopedisi. 26/473-475. Ankara: TDV Yayınları, 2002.

Uludağ, Süleyman. "Bâtın İlmi”. Türkiye Diyanet Vakfi İslam Ansiklopedisi. 5/188-189. İstanbul: TDV Yayınları, 1992.

Uludağ, Süleyman. "Sülûk”. Türkiye Diyanet Vakfi İslam Ansiklopedisi. 38/127. İstanbul: TDV Yayınları, 2010.

Uzun, Nihat. Kur'ân'in Batınî ve İşârî Yorumu Tefsir İlmi Açısından Bâtınî ve İşârî Yorumun İlmî Değeri. İstanbul: Kuramer Yayınları, 2018. 
Üzüm, İlyas. "Siffin Savaşı". Türkiye Diyanet Vakfi İslam Ansiklopedisi”. 37/108-109. İstanbul: TDV Yayınları, 2009.

Vahit, Göktaş. İlk Dönem Müellif Sufilerinden Kelâbâzînin Oruçla İlgili Yorumları. Ramazan ve Oruç. (ed. Berat Açl, Halis Kaya vd.), Haziran 2015, 107-117.

Yavuz, Yusuf Şevki. “Müşebbihe”. Türkiye Diyanet Vakfi İslam Ansiklopedisi. 32/156-158. İstanbul: TDV Yayınları, 2006.

Yllmaz, M. Faik. "Münâsebâtü'l-âyât ve's-süver". Türkiye Diyanet Vakfi İslam Ansiklopedisi. 31/569. İstanbul: TDV Yayınları, 2006.

Zehebî, Muhammed Huseyn. et-Tefsîr ve'l-mufessirûn. 3 Cilt. Kâhire: Mektebetu Vehbe, 2000. 